\title{
Communication Patterns During Application New Normal Covid-19 Protocol (Qualitative Descriptive Study In Seluma Regency)
}

\author{
Pola Komunikasi Pada Masa Penerapan \\ Protokol Covid-19 New Normal \\ (Studi Deskriptif Kualitatif Pada di Kabupaten Seluma)
}

\author{
Sugiarto, Yogi Arman1); Sari, Sapta ${ }^{2)}$; Octaviani, Vethy ${ }^{3)}$ \\ ${ }^{1,2,3)}$ Study Program of Communication Faculty of Social Science, \\ Universitas Dehasen Bengkulu \\ Email: vethyoc@gmail.com
}

\begin{abstract}
How to Cite :
Sugiarto, Yogi, Arman, Sapta, Sari \& Octaviani, Vethy. (2021). Pola Komunikasi Pada Masa Penerapan Protokol Covid-19 New Normal. Sengkuni Journal: Social Sciences and Humanities Vol. 2 No. 1 2021 page: 17-26. DOI: https://doi.org/10.37638/sengkuni.2.1.17-26
\end{abstract}

\section{ARTICLE HISTORY \\ Received [23 April 2021] \\ Revised [03 May 2021] \\ Accepted [06 June 2021]}

\section{KEYWORDS}

Communication Pattern,

Application,

Covid-19

Protocol, New Normal,

This is an open access article under the $\underline{C C-B Y-S A}$ license

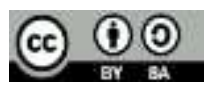

\begin{abstract}
ABSTRAK
Tujuan penelitian ini untuk mengetahui Pola Komunikasi Pada massa Penerapan Protokol Covid-19 New Normal Pada Dusun V Desa Sidoluhur Kabupaten Seluma. Metode penelitian ini adalah fleld research dengan pendekatan kualitatif. Pengumpulan data dilakukan dengan teknik observasi, wawancara dan dokumentasi. Teori yang digunakan pada penelitian ini adalah Pola Komunikasi Effendy menyebutkan ada tiga Pola Komunikasi yaitu Satu arah, Dua arah, dan Multi arah. Narasumber penelitian ini adalah Pemerintah Desa Sidoluhur dan Masyarakat Dusun V. Hasil penelitian menunjukan Pola Komunikasi antara Pemerintah Desa Sidoluhur pada Masyarakat Dusun V adalah Pola Komunikasi Satu arah karna dalam melakukan sosialisasi pencegahan tidak adanya interaksi secara langsung dan mengumpulkan massa. hal ini dapat dilihat dari kegiatan-kegiatan sosialisasi yang dilakukan namun belum mendapat respon yang baik dari masyarakat Dusun V Desa Sidoluhur. Faktor yang menyebabkan kurangnya kesadaran masyarakat tentang penting nya pola komunikasi yang baik di lakukan di masa covid-19 new normal ini adalah faktor internal dalam masyarakat sendiri
\end{abstract}

\section{ABSTRACT}

The purpose of this study was to determine the pattern of communication in the mass of the application of the Covid-19 New Normal protocol in the $V$ hamlet of Sidoluhur village, Seluma district. This research method is fleld research with a qualitative approach. The data was collected by means of observation, interview and documentation techniques. The theory used in this study is the Effendy Communication Pattern, which states that there are three patterns of 
communication, namely one-way, two-way, and multi-direction. The
resource persons of this research were the Sidoluhur Village
Government and the Dusun V. Community. The results showed that the
Communication Pattern between the Sidoluhur Village Government and
the Dusun V Community was a One-way Communication Pattern
because in carrying out prevention socialization there was no direct
interaction and mass gathering. This can be seen from the socialization
activities carried out but it has not received a good response from the
people of Dusun V Sidoluhur Village. The factors that cause a lack of
public awareness about the importance of good communication
patterns during the Covid-19 New Normal are internal factors in the
community it self.

\section{PENDAHULUAN}

Kota Wuhan Provinsi Hubei Tiongkok pada pertengahan Desember 2019 ditetapkan oleh Komite Intenasional nama SARS-CoV-2 ini tentang taksonomi virus (ICTV) pada 11 februari 2020, sebagai nama virus corona baru yang menyebabkan penyakit Covid-19, Virus corona atau severe acute respiratory syndrome coronavirus 2(SAR-CoV-2) adalah virus yang menyerang sistem pernapasan akibat infeksi SARSCoV-2 pada manusia. Presiden Indonesia Joko Widodo menandatangani Peraturan Pemerintah pada 31 Maret 2020 Nomor 21 Tahun 2020, mengatur pembatasan sosial berskala besar sebagai respons terhadap COVID-19, memungkinkan pemerintah wilayah untuk membatasi pergerakan orang \& barang masuk \& keluar berdasarkan wilayah masing-masing asalkan mereka sudah menerima izin berdasarkan kementerian terkait (pada hal ini Kementerian Kesehatan, pada Menteri Kesehatan, Terawan Agus Putranto).

Peraturan tadi juga mengungkapkan retriksi aktivitas yang dilakukan paling sedikit meliputi peliburan sekolah \& lokasi kerja, retriksi aktivitas keagamaan, \& retriksi aktivitas lokasi kerja atau fasilitas umum, Keputusan Presiden Nomor 11 Tahun 2020 ditandatangani yang menyatakan pandemi koronavirus. Virus corona atau severe acute respiratory syndrome coronavirus dua (SAR-CoV-dua) adalah virus yang menyerang sistem pernapasan penyakit dampak infeksi SARS-CoV-dua pada insan pertama kali berada di kota Wuhan. Provinsi Hubei Tiongkok dalam pertengahan Desember 2019. Nama SARS-CoV-dua ini ditetapkan Komite Intenasional mengenai Taksonomi Virus (ICTV), 11 februari 2020 menjadi nama virus corona baru yang mengakibatkan penyakit Covid-19.Pada 31 Maret 2020 Presiden Indonesia Joko Widodo menandatangani Peraturan Pemerintah Nomor 21 Tahun 2020 yang mengatur retriksi sosial berskala akbar sebagai respons terhadap COVID-19, yang memungkinkan pemerintah wilayah buat membatasi konvoi orang \& barang masuk \& keluar berdasarkan wilayah masingmasing asalkan mereka sudah menerima keputusan pada Menteri Kesehatan, Terawan Agus Putranto).

Peraturan tadi pula mengungkapkan bahwa retriksi aktivitas yang dilakukan paling sedikit mencakup peliburan sekolah \& loka kerja atau fasilitas umum. Pada saat yang sama, Keputusan Presiden Nomor 11 Tahun 2020 pula ditandatangani, yang menyatakan pandemi koronavirus Walaupun tidak mengajukan PSBB, seluruh yang dilakukan oleh Pemerintah Provinsi Bengkulu dalam penanganan Covid-19 dipastikan mengikuti kebijakan secara nasional. (Gema Pertiwi, 2020). 


\section{LANDASAN TEORI}

New normal adalah kebijakan terkini \& dipercaya terbaik oleh pemerintah buat menjalankan kehidupan pada tengah pandemi Covid-19. Setelah memberlakukan retriksi kegiatan sosial berskala besar, dampaknya tidak hanya dalam perubahan gaya hayati warga saja, tetapi jua ekonomi Negara yang berhenti. Inilah mengapa new normal dipercaya menjadi jalan keluar terbaik pada tengah pandemi Covid-19, berarti hayati \& menjalani kegiatan, pekerjaan, \& hubungan menggunakan orang lain menggunakan cara yang baru. Pola Komunikasi merupakan proses yang didesain buat mewakili fenomena keterpautannya unsur-unsur yang pada cakup bersama keberlangsunganya, guna memudahkan pemikiran secara sistematik \& logis. Komunikasi merupakan galat satu bagian menurut hubungan antar insan baik individu juga grup pada kehidupan seharihari.Dari pengertian ini jelas bahwa Komunikasi melibatkan sejumlah orang dimana seorang menyatakan sesuatu pada orang lain, jadi yang terlibat pada Komunikasi itu merupakan insan itu. Komunikasi berawal menurut gagasan yang ada pada seseorang, gagasan itu di olahnya menjadi pesan \& di kirimkan melalui media tertentu kepada orang lain sebagai penerima pesan dan sudah mengerti pesannya kepada pangirim pesan. Dengan menerima tanggapan dari si penerima pesan itu, pengirim pesan dapat menilai efektifitas pesan yang di kirimkannya.

Berdasarkan tanggapan itu, pengirim dapat mengetahui apakah pesannya di mengerti \& sejauh mana pesanya di mengerti oleh orang yang di kirimi pesan itu. Desa Sidoluhur terdiri dari VIII ( Delapan ) Dusun dan memiliki jumlah penduduk sebanyak 1920 jiwa Dari VIII ( Delapan ) Dusun tersebut hasil pengamatan yang dilakukan peneliti, warga Dusun Vmayoritas berprofesi pekerjaan adalah seorang pedagang dan kuli bangunan sering berkontak langsung kepada orang banyak dan bekerja di luar daerah Pemerintah Desa diminta untuk membentuk relawan gugus tugas yang di kepalai oleh kepala Desa dengan susunanya kepala Dusun sebagai kunci utama melaksanakan aturan Pemerintah Desa melalui Kepala Desa mulai pada 5 april 2020, yang diatur dalam Keputusan Presiden RI Joko Widodo Nomor 11 tahun 2020 tentang kedaruratan kesehatan masyarakat.

Sebelum di berlakukan nya penerapan New Normal Covid-19. Pola Komunikasi yang terjadi pada Masyarakat Dusun V Desa Sidoluhur cenderung melakukan aktivitas di dalam rumah dan jika ingin berkomunikasi sehari-hari menggunakan bantuan media komunikasi. Setelah di berlakukan nya penerapan New normal di Indonesia Khususnya di DusunV Desa Sidoluhur Kabupaten Seluma, aktivitas di luar rumah sudah di perbolehkan dan tempat-tempat keramaian sudah di buka kembali seperti pasar dan tempat-tempat keramaian lainnya sudah di perbolehkan dengan menggunakan protokol New normal, tetapi masih ada warga Dusun V Desa Sidoluhur yang tidak memakai kelengkapan protokol New normal salah satu nya menggunakan masker pada saat ketempat keramaian, dan Pola Komunikasi masyarakat yang sebelumnya.

Masyarakat berkomunikasi dengan bantuan media komunikasi Pola komunikasi yang digunakan adalah Satu Arah dan masyarakat pada saat ini menggunakan pola komunikasi secara langsung. Komunikasi langsung merupakan proses komunikasi yang dilakukan secara langsung atau Pola Komunikasi Dua Arah dan Multi Arah. Berdasarkan hasil observasi menunjukan bahwa Masyarakat Dusun V Desa Sidoluhur aktivitasnya sering berpergian ke luar daerah dan berkontak langsung dengan orang banyak maka dari hasil pengamatan peneliti, setelelah diterapkannya New normal masyarakat menggunakan pola komunikasi secara tidak langsung atau menggunakan bantuan media komunikasi dan setelah diterapkannya New normal Pola Komunikasi masyarakat menjadi secara langsung atau berkomunikasi tanpa menggunakan bantuan media komunikasi. 


\section{METODE PENELITIAN}

Penelitian dilakukan dengan menggunakan metode Kualitatif yang dilakukan pada bulan Desember 2020, dengan teknik wawancara terhadap masyarakat usun $v$ dan pemerintah desa Sidoluhur yang dijadikan narasumber penelitian dan observasi di lapangan.

\section{HASIL DAN PEMBAHASAN}

Selama penulis melaksanakan penelitian di Desa Sidoluhur Kabupaten Seluma, peneliti melihat dan mengamati mengenai kegiatan-kegiatan Kepala Desa dan Kepala Dusun V Desa Sidoluhur dalam menjanlankan pelayanan penerapan protokol covid-19 new normal di Desa Sidoluhur Kabupaten Seluma, Kepala Desa dan Kepala Dusun V memiliki peran yang sangat penting untuk menunjang kegiatan-kegiatan serta kebijakan yang di tetapkan oleh pemerintah pusat mengenai penerapan protokol covid-19 new normal di Desa Sidoluhur Kabupaten Seluma. Dalam hal ini Kepala Desa dan Kepala Dusun V sebagai penghubung antara Pemerintah Desa dengan Masyarakat yang mampu menciptakan Komunikasi dua arah dengan menyampaikan informasi dari Pemerintah kepada Masyarakat sehingga akan tercipta hubungan yang baik antara pemerintahan Desa dengan masyarakat, dan juga mengamati kegiatan-kegiatan Masyarakat Dusun V saat beraktivitas di dalam Desa maupun luar Desa Sidoluhur.

Adapun hasil penelitian ini berdasarkan kerangka teori pada bab sebelumnya penulis menggunakan teori pola komunikasi Effendy sebagai berikut:

1. Pola Komunikasi satu arah

Berdasarkan hasil penelitian yang dilakukan oleh penulis dengan Kepala Desa Sidoluhur Kabupaten Seluma, melalui proses wawancara. Apakah Bapak sudah melakukan sosialisasi penerapan new normal di Desa Sidoluhur, jawaban yang didapatkan dari Bapak Sutrisno mengatakan bahwa:

"Sudah, dilakukan di bulan juli upaya yang kami lakukan seperti penyemprotan di sinfektan ke lokasi-lokasi yang sering digunakan masyarakat untuk berkumpul diantara nya Balai Desa, Balai Posyandu, Masjid, rumah-rumah warga, dan lain-lain." Dan dari jawaban yang di dapat dari Bapak Surtisno di atas Penulis juga menanyakan mengenai, dengan bantuan media apa yang dilakukan Bapak dalam melakukan sosialisasi kepada Warga Dusun V jawaban yang di dapatkan dari Bapak Romlan selaku Kepala Dusun mengatakan bahwa:

"Seperti anjuran yang telah di tetapkan untuk tidak berkerumunan tentunya dalam melakukan sosialisasi kepada warga saya menggunakan menggunakan mikrofon sembari melakukan penyemprotan disinfektan." Dan dari jawaban yang di dapatkan oleh Pemerintah Desa Sidoluhur Kabupaten Seluma tersebut peneliti juga menanyakan mengenai cara berkomunikasinya seperti apa yang Bapak lakukan dalam melakukan sosialisasi kepada masyarakat Dusun V. Dari hasil wawancara yang dilakukan kepada Bapak Romlan, menjabat sebagai Kepala Dusun V Desa Sidoluhur Kabupaten Seluma mengungkapkan bahwa:

"Baik dalam melakukan sosialisasi kami memakai mobil Desa bersama kaduskadus yang lain menggunakan mikrofon menghimbau agar menggunakan masker saat ingin berpergian dan jaga jarak. "Berdasarkan hasil penelitian yang dilakukan penulis melalui proses wawancara apakah Kepala Desa Sidolohur selaku gugus tugas covid-19 sudah melakukan sosialisasi tentang penerapan new normal, Bagaimana tanggapan Bapak/lbu setelah dilakukanya sosialisasi sebagai berikut, jawaban yang didapatkan dari Suprianto Warga Dusun V yang berprofesi sebagai Kuli Bangunan sering berpergian ke luar Daerah mengatakan: 
"Tanggapan saya, setelah diadakan sosialisasi memang sangat direspon masyarakat, karena dengan diadakan sosialisasi tentang new normal covid-19, masyarakat bisa lebih memahami tentang bahaya penyakit covid-19 yang sedang melanda Negara kita." Dari jawaban lain didapat dan diperkuat dari warga Dusun V lainya, jawaban dari Ibu Sukini berprofesi sebagai pedagang di pasar sering berinteraksi dengan orang banyak mengatakan:

"Tanggapan saya sangat baik setelah diadakan sosialisasi tentang penerapan new normal disini saya lebih bisa mengerti tentang bahaya penyakit covid-19." Bapak Saparin dengan singkatnya juga mengungkapakan selaku Tokoh Masyarakat."Tanggapan saya sangat baik dengan diadakannya sosialisasi tentang masalah penyakit covid-19 di Desa." Pertanyaan selanjutnya yang peneliti tanyakan mengenai.Apakah menurut Bapak/lbu sosialisasi tentang penerapan new normal di Desa Sidoluhur sudah berjalan efektif, apa alasanya.

Jawaban yang di dapat dari Suprianto mengungkapkan sebagai berikut:

"Sosialisasi tentang new normal menurut saya sudah sangat efektif, karena sebagian masyarakat sangat merespon anjuran pemerintah namun masih ada warga yang tidak nenggunakan masker saat beraktivitas diluar rumah." Jawaban serupa juga diungkapkan oleh Ibu Sukini sebagai berikut."Penerapan new normal cukup baik berjalan efektif, meskipun sebagai masyarakat masih banyak mengabaikan protokol kesehatan yang dianjurkan pemerintah." Jawaban yang di dapat dari Bapak Saparin mengungkapkan sebagai berikut:

"Tentang penerapan new normal sudah cukup efektif, karena masyarakat sebagian besar sudah mengerti tentang masalah bahaya penyakit covid-19." Dapat penulis simpulkan bahwa pemeritah Desa Sidoluhur Dusun V sudah melaksanakan tugas dan fungsinya dengan baik, salah satunya dengan melakukan kegiatan penyemprotan di sinfektan, diadakan juga sosialisasi keliling menggunakan mobil pentaris Desa serta pengeras suara tentang penerapan new normal, sehingga masyarakat Dusun $\mathrm{V}$ mengerti tentang bahaya penyakit covid-19, di terapkan juga untuk tidak berkerumunan tentunya dalam melakukan sosialisasi kepada masyarakat Dusun $\mathrm{V}$, dan pemerintah Desa juga menghimbau agar menggunakan masker saat ingin berpergian dan jaga jarak. karena sebagian masyarakat sangat merespon anjuran pemerintah namun masih ada warga yang tidak menggunakan masker saat beraktivitas diluar rumah.

\section{Pola Komunikasi Dua Arah}

Berdasarkan hasil penelitian yang di lakukan oleh penulis dengan Kepala Desa Sidoluhur Kabupaten Seluma, melalui proses wawancara bagaimana cara Bapak/lbu berkomunikasi dengan pihak-pihak terkait untuk memutus rantai penyebaran covid-19, jawaban yang di dapatkan dari Bapak Sutrisno mengatakan bahwa:

"Tentunya pemerintah Desa Sudah menjalankan anjuran dari mentri kesehatan mengacu dengan adanya aturan protokol kesehatan untuk memutus penyebaran covid19, dan kami selalu menghimbau kepada seluruh warga masyarakat Desa Sidoluhur untuk selalu menjaga kesehatan menggunakan protokol kesehatan saat ingin berpergian minimal menggunakan masker." Bapak Sutrisno dengan singkatnya juga menjawab tentang mengenai apakah cara berkomunikasi antara Pemerintah Desa kepada masyarakat sudah berjalan efektif "Sudah walaupun sanggahan-sanggahan masih ada dari beberapa warga masih sedikit lalai tidak menggunakan masker."

Setelah penulis mendapatkan jawaban dari semua pertanyaan yang telah peneliti ajukan, ada satu pertanyaan lagi yang peneliti berikan kepada Kepala Desa Sidoluhur bagaimana respon masyarakat setelah dilakukan sosialisasi. Dari hasil wawancara yang dilakukan kepada Bapak Sutrisno mengungkapkan bahwa "tentunya respon masyarakat sangat baik, karena cara untuk mata rantai itu dari diri sendiri". 
Bapak Romlan dengan singkatnya juga menjawab tentang mengenai tindakan apa yang akan Bapak ambil jika ada warga yang tidak menggunakan masker saat berada di tempat kerumunan. "Memberikan peneguran jika ada salah satu warga yang tidak mengunakan masker saat berkerumunan dan memanggil ke kantor Desa untuk diberikan masker." Dan selanjutnya pertanyaan mengenai Cara berkomunikasinya berjalan seperti apa satu arah, dua arah, atau, multi arah. Jawaban yang di dapat dari suprianto mengungkapkan sebagai berikut:

"Ya kalau berkomunikasi sama teman atau lagi bekerja enggak pakek si soal nya engap kalau dipakek terus." Dari jawaban yang di dapat dari lbu Sukini mengungkapkan sebagai berikut: "Disini saya berkomunikasi sangat lancar karena sebagai pedagang saya harus bisa berkomunikasi dengan baik dengan pembeli walau kadang saya tidak mengunakan masker saat lagi berjualan karna kurang nyaman dan engap, ya gimana lagi ya nama nya kebutuhan harus berani ngambil resiko." Selanjutnya jawaban yang di dapat dari Bapak Saparin mengungkapkan sebagai berikut:

"Cara berkomunikasi di Desa menurut saya sudah sangat efektif baik Kepala Desa maupun Kepala Dusun sudah menjalankan tugasnya dengan baik, seperti penyemprotan disenfektan setiap rumah-rumah warga dan tempat-tempat orang sering berkumpul." Penulis juga menanyakan tentang Jika ada pendatang dari luar Desa, Bagaimana respon Bapak/lbu lakukan. Jawaban yang di dapat dari warga Dusun V Suprianto mengungkapkan "Jika ada seseorang pendatang dari Desa lain selalu kami anjurkan periksa kesehatan kepukesmas terdekat."

Bapak Saparin juga dengan singkatnya menjawab tentang apa respon Bapak/lbu ketika melihat warga yang tidak menggunakan masker saat berada di tempat kerumunan"apabila saya melihat warga tidak mengunakan masker saat berkerumunan kami selalu mengingatkan untuk mematuhi anjuran pemerintah karena itu menyangkut kesehatan kita sendiri dan orang lain." Dapat penulis simpulkan bahwa pemerintah Desa Sidoluhur Dusun V Sudah menjalankan anjuran dari mentri kesehatan mengacu dengan adanya aturan protokol kesehatan untuk memutus penyebaran covid-19, dan kami selalu menghimbau kepada seluruh warga masyarakat Desa Sidoluhur Dusun V untuk selalu menjaga jarak dan menggunakan masker, walaupun sanggahan-sanggahan masih ada dari beberapa warga yang lalai tidak menggunakan masker, serta memberikan peneguran jika ada salah satu warga yang tidak mengunakan masker saat berkerumunan dan memanggil ke kantor Desa untuk diberikan masker.

3. Pola Komunikasi Multi Arah

Penulis juga menanyakan mengenai, seperti apa cara berkomunikasi dalam melakukan suatu kegiatan masyarakat pada masa new normal di Desa Sidoluhur. Dari hasil wawancara yang dilakukan dengan Bapak Sutrisno Kepala Desa Sidoluhur Kabupaten Seluma mengungkapkan bahwa: "Di dalam suatu acara pembagian BLT(Bantuan langsung tunai) DD(Dana Desa) dan sudah dilakukan sesuai ketentuan menggunakan protokol kesehatan dalam melakukan suatu kegiatan, dalam penyampaian untuk masyarakat berkumpul bertempat di Balai Desa Sidoluhur, dan pada acara tersebut bila mana ada masyarakat yang tidak menggunakan masker maka tidak akan dilayani dan tidak diperbolehkan masuk."

Pertanyaan selanjutnya yang peneliti tanyakan adalah apakah Bapak/lbu sudah mematuhi protokol kesehatan dalam penerapan new normal, apa alasanya. Jawaban di dapat dari Suprianto warga Dusun $V$ yang berprofesi sebagai kuli bangunan mengungkapkan "jujur saja saya kurang mematuhi anjuran pemerintah karena saya apabila sedang bekerja memakai masker merasa kurang nyaman." Penulis juga menanyakan kepada Bapak Sutrisno Selaku Kepala Desa Sidoluhur, Apakah kegiatan Keorganisasian di Desa Sidoluhur Dusun V masih diperbolehkan, "untuk sementara waktu ditiadakan dulu seperti kegiatan PKK itu diliburkan dulu karna untuk pencegahan 
pengumpulan masa" Dan penulis juga menanyakan, Apakah lbu saat berdagang atau beraktivitas diluar rumah sering menggunakan masker jawaban yang didapat sebagai berikut:

"Disini saya sabagai pedagang jujur kurang mematuhi protokol kesehatan seperti menggunakan masker karena kurang merasa nyaman saat berjualan." Penulis juga menanyakan tentang jika sedang ada musyawarah atau pertemuan yang melibatkan orang banyak cara bekomunikasinya seperti apa. Jawaban yang di dapat dari warga Dusun V Bapak Saparin "apabila kami sedang bermusyawarah melibatkan orang banyak kami selalu mematuhi protokol kesehatan jaga jarak dan pakai masker."

Dapat penulis simpulkan bahwa dalam penyampaian untuk masyarakat berkumpul pada acara pembagian BLT DD ( Bantuan Langsung Tunai Dana Desa )bila mana ada masyarakat yang tidak menggunakan masker maka tidak akan dilayani dan tidak diperbolehkan untuk menghadiri acara tersebut. Dan masih banyak warga yang lalai akan menggunakan masker saat berkomunikasi maupun bekerja, dengan alasan pada saat sedang bekerja memakai masker merasa kurang nyaman. Dari hasil observasi, wawancara, dan dokumentasi peneliti dapat simpulkan bahwa usaha yang dilakukan oleh Pemerintah Desa Sidoluhur Kabupaten Seluma sudah mematuhi Protokol kesehatan yang diberlakukan oleh mentri kesehatan, kegiatan berupa sosialisasi keliling menggunakan mikrofon serta menggunakan mobil pentaris Desa yang di lakukan kepala Dusun $\mathrm{V}$ serta penyeprotan disenfektan di setiap rumah dan lokasi-lakasi berkumpul, hal ini sangat di harapakan dapat menarik perhatian dari warga masyarakat Desa Sidoluhur Dusun $\mathrm{V}$ untuk peduli akan penggunaan protokol kesehatan, walau masih ada warga yang sedikit lalai, dari hasil Observasi, wawancara, dan Dokumentasi Penulis menyimpulkan bahwa Pola Komunikasi yang digunakan adalah satu arah karena Pemerintah Desa menyampaikan Sosialisasi penerapan new normal tidak secara langsung menggunakan bantuan mikrofon dan pemasangan spanduk protokol kesehatan, tidak adanya interaksi antara Pemerintah Desa Sidoluhur Dusun V dan masyarakat Dusun $\mathrm{V}$ tidak ada feed back dalam Pola Komunikasi ini.

Penulis menyimpulkan bahwa pola Komunikasi antara Pemerintah Desa Sidoluhur kepada masyarakat Dusun V adalah Pola Komunikasi Satu arah, tidak secara langsung, hal dapat dilihat pada kegiatan-kegiatan sosialisasi pada gambar diatas berupa penyemprotan disinfektan, pemasangan spanduk disetiap persimpangan jalan dan beberapa rumah, dan penyampain patuh Protokol menggunakan mikrofon menggunakan mobil pentaris Desa. Sedangkan pesan komunikasi dua arah yang di sampaikan oleh pemerintah Desa Sidoluhur kepada masyarakat Dusun V Belum objektif, karna respon dari masyarakat masih kurang baik Masyarakat Dusun $\mathrm{V}$ masih ditemukan kelalaian untuk mematuhi Protokol Kesehatan yang di berlakukan, dalam melakukan aktivitas di luar rumah masih ada yang tidak menggunakan masker, padahal Pemerintah Desa Selaku tim gugus tugas covid-19 sudah sering kali mensosialisasikan untuk beraktivitas di luar Desa maupun di dalam Desa saat berkomunikasi harus mematuhi protokol, hal ini dilihat dari interaksi melalui aktivitas masyarakat Desa Sidoluhur Dusun $\mathrm{V}$ itu sendiri dalam bekerja, dengan alasan tidak mengunakan masker engap dan agak susah bernafas pada saat melakukan aktivitas dalam bekerja.

Penulis menyimpulkan bahwa pola Komunikasi dua arah antara Pemerintah Desa Sidoluhur kepada masyarakat dusun $v$ tidak objektif karna tidak adanya sosialisasi secara langsung yang dilakukan oleh pemerintah desa sidoluhur dusun $v$ hal ini berdasarakan observasi dan wawancara yang peneliti dapat menjelaskan bahwa dalam aktivitas kegiatan yang dilakukan masyarakat Desa sidoluhur Dusun V masih ditemukan kelalaian dalam mematuhi protokol yang berlakukan. Dan sedangkan Pola Komunikasi Multi arah di Desa Sidoluhur Dusun V ini Dibatasi dan kegiatan keorganisasian Desa sementara waktu ditiadakan dahulu untuk pencegahan penumpukan massa, untuk 
kegiatan yang bersifat darurat dan harus dilaksanakan seperti kegiatan Musyawarah Desa bisa dilakukan namun dibatasi bisa menggunakan bantuan media komunikasi dan hanya beberapa orang saja yang bisa menghadiri sesuai ketentuan yang diberlakukan pemerintah. Penulis menyimpulkan bahwa pola Komunikasi multiarah dilakukan secara tidak langsung menggunakan bantuan media komunikasi dan bisa dihadiri secara langsung bila mana kegiatan musyawarah Desa yang bersifat sangat penting untuk mengumpulkan masyarakat.

Dari hasil pengumpulan data yang penulis dapat berdasarkan Observasi, Wawancara, dan Dokumentasi kepada Pemerintah Desa Sidoluhur dan Masyarakat Dusun $\mathrm{V}$ Penulis mengambil kesimpulan dari teori Effendy yang penulis gunakan dan fenomena yang terjadi dimasa pandemi Covid-19 New normal Pada Dusun V Desa Sidoluhur Kabupaten Seluma ini, Pola Komunikasi yang tepat dilakukan adalah Pola Komunikasi Satu arah dengan alasan untuk mencegah penularan virus covid-19 maka dari itu penulis menyarankan untuk kegiatan secara langsung untuk dikurangi dan Pola komunikasi satu arah ini sangat tepat diberlakukan karna interaksi secara tidak langsung lebih efektif untuk mencegah penularan covid-19.

\section{KESIMPULAN DAN SARAN}

Pola Komunikasi yang terjadi antara Pemerintah Desa dan Masyarakat desa sidoluhur dusun $V$ ini yang lebih diterapkan adalah Pola Komunikasi Satu Arah dikarenakan Sosialisasi Penerapan Protokol Kesehatan yang dilakukan oleh pemerintah Desa Sidoluhur Selaku relawan gugus tugas covid-19 ini tidak secara langsung namun belum mendapat respon yang baik dari masyarakat sendiri karna masih banyak masyarakat yang tidak mentaati protokol kesehatan yang diberlakukan dalam berinteraksi ataupun berkomunikasi seperti menggunakan masker dan menjaga jarak dari kerumunan dan untuk kegiatan keorganisasian sementara diliburkan karna untuk mencegah penumpukan masa, Pola Komunikasi yang digunakan oleh Pemerintah Desa Sidoluhur Dusun V selaku gugus tugas covid-19 adalah Pola Komunikasi Satu Arah karna dalam melakukan sosialisasi pencegahan tidak adanya interaksi secara langsung dan mengumpulkan massa. Setelah melakukan analisis, maka saran-saran yang dapat peneliti berikan adalah sebagai berikut:

1. Pemerintah Desa Sidoluhur Kabupaten Seluma perlu banyak melakukan sosialisasi dan harus mampu mengelola kendali informasi terkait covid-19 jangan 
sampai masyarakat cemas dalam mengahadapi wabah ini karena ketidak jelasan informasi.

2. Kepada Masyarakat Dusun V Desa Sidoluhur Kabupaten Seluma agar dapat menambah wawasan baik itu internet atau shering langsung kepada pemerintah Desa terkait penanganan covid-19.

3. Pembagian masker, hansdtainizer, dan bak air untuk cuci tangan setiap Dusun guna untuk meningkatkan kesadaran masyarakat tentang disiplin protokol kesehatan yang berlaku.

\section{DAFTAR PUSTAKA}

Ali, Lukman. 1995. Kamus Besar Bahasa Indonesia. Balai Pustaka.

Azra, Azyumardi. 2007. Masyarakat multicultural. Journal Middya Boty JSA Vol. 1 No. 2: 2017

Basyiruddin, Usman. 2002. Media Pendidikan. Jakarta:Ciputat Press.

Badudu J.S, dan Zain, Sutan Mohammad. 1996. Kamus Umum Bahasa Indonesia. Jakarta: Pustaka Sinar Harapan.

Effendy, Onong Uchjana. 1986. Dimensi Komunikasi. Bandung:Alumni.

Effendy, Onong Uchjana. 1989. Kamus Komunikasi Bandung:Mandar Maju.

Furnival, S. 1967. Masyarakat Multikultural. Journal Middya Boty JSA Vol. 1 No. 2: 2017

Fajrian, Meita. 2020. 28 Mei. Makna New Normal Di Tengah Pandemi Virus Corona Covid19. Liputan6.com

Farhana, Karla. 2020. 05 Juni. Strategi Menjalani Era New Normal dari Para ahli.Liputan6.com

Gading, Arya. 2020. Lima tenaga medis positif covid-19 RSUD Tais tutup pelayanan. https://getsnap.link/fpkcBc47jcj

Harys, 2020. Penelitian Terdahulu. https://www.jopglass.com/penelitian-terdahulu/ Iskandar, Abdul, Halim. 2020. Protokol normal baru desa. http://Kemendesa.go.id

Iskandar, Abdul, Halim. 2020. Protokol normal baru desa. https://Covid.go.id/p/protokol/kepmendesa-pdtt-63-tahun-2020-protokolnormal-baru-desa

Majone, dan Wildavski. 1979. Penerapan implementasi sebagai penilaian. Bandung: Perpustakaan Universitas Pendidikan Indonesia.

Novika, Soraya. 2020. Sederet alasan pemerintah terapkan new normal. https://m.detik.com/finance/berita-ekonomi-bisnis/d-5039532/sederet-alasanpemerintah-terapkan-new-normal/2

Neumen, 2010. Tujuan dan Fungsi Penelitian Terdahulu. Malang:Universitas Muhammadyah Malang

Prasanti, Dina. Pola Komunikasi Organisasi Dalam Mempertahankan Loyalitas Anggota. Jawa tengah: Universitas Muhammadiyah Surakarta. 2017.

Pertiwi, Gema. 2020. Implementasi psbb Gubernur Rohidin ikuti video converence bersama para menteri. https://bengkuluprov.go.id/implementasi-psbbgubernur-rohidin-ikuti-video-converence-bersama-para-mentri

Rundengan, nabella. Pola Komunikasi antar Pribadi Mahasiswa Papua Di Lingkungan Fakultas IImu Sosial Dan IImu Politik. Manado: Universitas Sam Ratulangi. 2013.

Rahardjo, 1999. Pengantar Sosiologi Pedesaan dan Pertanian. Yogyakarta: Gadjah Mada University Press.

Satori, Djam'an dan Komariah, Aan. 2014. Metode Penelitian Kualitatif. Bandung: Alfabeta. 
Sugiyono. 2014. Metode Penelitian Pendekatan Kualitatif, Kuantitatif Dan R\&D. Bandung: Alfabeta.

Tonnies, Ferdinand. 1855. Pengertian Masyarakat Desa. Yogyakarta:Gadjah Mada University Press 